\section{Estudo \\ CoDebate}

em Testão

Dlanejamento
Revista Estudo \& Debate, Lajeado, v. 28, n. 4, 2021. ISSN 1983-036X

DOI: http://dx.doi.org/10.22410/issn.1983-036X.v28i4a2021.2819

\title{
DIESELGATE E O CAPITALISMO NO SÉCULO XXI: UMA ANÁLISE DO CASO VOLKSWAGEN E A MÁ-FÉ NAS RELAÇÓES CONSUMERISTAS
}

\author{
Felipe Augusto Silva Custódio ${ }^{1}$, Marcelle Mariá Silva de Oliveira ${ }^{2}$
}

\begin{abstract}
Resumo: O presente artigo analisa o caso concreto do Dieselgate da Volkswagen sob o enfoque do Direito do consumidor e as consequências quanto a inobservância dos preceitos consumeristas nas relaçóes entre fornecedores e consumidores, bem como os prejuízos que o capitalismo exacerbado causa a sociedade nos dias atuais. A sociedade atual é predominantemente pautada pelo consumo, em que diariamente as pessoas adquirem produtos ou serviços, no intuito de sanar as suas necessidades. Entretanto, aqueles que são responsáveis pelos maiores percentuais de riquezas do mundo, muitas vezes não respeitam os consumidores de forma adequada, agindo em patente descompasso com o princípio da boa-fé objetiva. Nesse sentido, a preocupaçáo dos autores que construíram a ideia do "comum" está vívida e exemplificada.
\end{abstract}

Palavras-chave: Dieselgate. Volkswagen. Comum. Direito do Consumidor. Princípio da boa-fé objetiva. Relações consumeristas.

\section{DIESELGATE AND CAPITALISM IN THE 21ST CENTURY: AN ANALYSIS OF THE VOLKSWAGEN CASE AND BAD FAITH IN CONSUMER RELATIONS}

\begin{abstract}
This article analyzes the specific case of Volkswagen Dieselgate under the focus of consumer law and the consequences of noncompliance with consumer precepts in relations between suppliers and consumers, as well as the damage that exacerbated capitalism causes to society today. Today's society is predominantly consumer-driven, where people buy goods or services on a daily basis to heal their needs. However, those who
\end{abstract}

1 Mestre em Direito pela Faculdade de Direito Milton Campos. Pós-graduado em Direito Penal e Processo Penal pela Universidade Candido Mendes/RJ. Pós-graduado Direito Tributário pela PUC/MG. Pósgraduado em Direito do Trabalho e Processo do Trabalho pelo Centro Universitário UNA de Sete Lagoas. Graduado em Direito pelo Centro Universitário de Sete Lagoas/UNIFEMM. Professor de Direito do Trabalho, Processo do Trabalho e Direito Empresarial do Centro Universitário de Sete Lagoas/UNIFEMM. Advogado.

2 Mestra em Direito pela Faculdade de Direito Milton Campos. Especialista em Advocacia Cível pela Escola Superior de Advocacia de Minas Gerais. Especialista em Docência do Ensino Superior, com ênfase no Ensino Jurídico pela Faculdade Arnaldo. Graduada em Direito pela Pontifícia Universidade Católica de Minas Gerais - PUC Minas. Advogada. 
are responsible for the largest percentages of the world's wealth often do not adequately respect consumers, acting in patent disregard for the principle of objective good faith. In this sense, the concern of the authors who constructed the idea of the "common" is vivid and exemplified.

Keywords: Dieselgate. Volkswagen. Common. Consumer Law. Principle of objective good faith. Consumer relations.

\section{INTRODUÇÁO}

O consumo é intrínseco ao convívio social, assim, como resposta ao anseio resultante das especificidades deste tipo de relação, nasce o Direito do Consumidor, que possui como objetivo a proteção e defesa dos consumidores, o qual, no Brasil, tem como base normativa o comando constitucional.

Por determinação legal, as relaçóes consumeristas devem ser pautadas em uma negociação sem vícios, na qual o consumidor cumpre o seu dever de pagar e quitar o bem ou o serviço adquirido, e o fornecedor de entregar aquilo que foi pactuado entre as partes, ou seja, o princípio da boa-fé objetiva é elemento essencial nesta relação, que possui como norte o cumprimento da obrigação sem disfunções e o dever de não lesar conscientemente.

Tendo em mente que o consumidor é a parte mais frágil da relação, o caso concreto do Dieselgate da Volkswagen traz uma grave e perigosa realidade quanto a conduta das grandes empresas, em que o capitalismo e o lucro excessivo deformam as relaçóes e causam prejuízos desmedidos.

Para o desenvolvimento da investigação do artigo foi utilizada a metodologia teóricodocumental, com técnica dedutiva através de pesquisas bibliográficas, e tendo como fonte de dados artigos, obras doutrinárias nacionais e internacionais, utilizando como marco teórico os autores Pierre Dardot, Christian Laval e Humberto Teodoro Junior.

\section{NOÇÓES GERAIS DE DIREITO DO CONSUMIDOR}

O Direito do Consumidor é o ramo específico que tutela as relações de consumo, buscando, em especial, a defesa de um dos polos desta relação, o consumidor.

Embora os autores do anteprojeto da lei que veio a regular o assunto (GRINOVER, 2011) ensinem que a movimentação legislativa que culminou na criação do direito consumerista do Brasil tenha iniciado antes mesmo da promulgação da Constituição de 1988, fato é que a referida Carta Magna representa o marco principal para a normatização deste direito no país.

É que além de prever, em seu art. $5^{\circ}$, a proteção ao consumidor como direito fundamental, o art. 48 do ADCT estipulou prazo para que o código de defesa fosse elaborado.

Tal acontecimento, como elucida Leonardo de Medeiros Garcia, relaciona-se com a interseção do direito público e privado, acompanhando uma tendência mundial. Veja-se:

A Constituição Federal de 1988, incorporando uma tendência mundial de influência do direito público sobre o privado, chamada pela doutrina de "constitucionalizaçấo do 
Direito Civil" ou de "Direito Civil Constitucional", adotou como princípio fundamental, estampado no art. $5^{\circ}$, XXXII, "a defesa do consumidor". (GARCIA, 2017, p. 17).

\section{Concordando com o jurista acima citado, Bruno Miragem esclarece que:}

O CDC, como é sabido, surge da expressa determinação constitucional (artigo 48 do $\mathrm{ADCT})$. E tanto na consagraçáo do direito do consumidor como direito fundamental (artigo $5^{\circ}$. XXXII), no seu estabelecimento como princípio da ordem econômica (artigo $170, V)$, quanto na previsão expressa da competência legislativa da União para legislar sobre responsabilidade por danos causados (artigo 24, VIII), resta identificado como sujeito específico, titular de um direito subjetivo constitucional. Assim, a referência à relação de consumo, como realiza o Código de Defesa do Consumidor, constitui na verdade uma estratégia legislativa para identificar a partir desta um dos seus sujeitos, e determinar-lhe a proteção. Não há, portanto, uma determinaçáo constitucional de proteção ao consumo, mas do consumidor - nas palavras de Claudia Lima Marques, um novo sujeito pósmoderno de direitos.

A consagração de direitos fundamentais para sujeitos de relaçóes privadas, como o consumidor na relação de consumo, choca-se com o conceito liberal clássico de Constituição, e sua definiçáo como documento de organização e limitação do poder político. Todavia, é animada por uma nova concepção sobre o sentido e a função da Constituição, construído a partir da dignidade da pessoa humana, coo base da liberdade, da justiça e da paz - de acordo com o preconizado pela Declaraçáo Universal dos Direitos do Homem da ONU, de 10 de dezembro de 1984 .

E, em face deste novo significado de Constituição, cujas raízes históricas fogem do objeto do presente estudo - mas que guardam sua origem nas transformaçôes sociais profundas desde o início do século XX - um novo fenômeno de aproximação entre as esferas pública e privada passa a ser realizado. A separação entre o público e o privado, que no direito manifestava-se, até então, por rígida dicotomia visando a preservação da liberdade individual do homem burguês em relação ao Estado, é superada, sobretudo, pela elevaçáo ao nível constitucional de inúmeras matérias tradicionalmente reguladas por normas ordinárias. (...) No Brasil, os reflexos deste fenômeno da constitucionalização do direito civil vão se apresentar, de modo expressivo, na Constituição de 1988, por intermédio da disciplina constitucional dos temas vinculados historicamente ao direito privado, e regulados com pretensão exaustiva pelo Código Civil de 1916. (...)

A incorporação, pela Constituição da República, de relações jurídicas antes determinadas pelo direito civil, faz com que os direitos de titularidade dos sujeitos destas relaçóes jurídicoprivadas também comportem uma alteração qualitativa de status, passando a se caracterizar com direitos subjetivos de matriz constitucional. E esta alteração, antes de significar meto artifício dogmático, tem consequências concretas na tutela dos respectivos direitos. No minimo, estabelecendo os como preferenciais em relação a outros direitos de matriz infraconstitucional. No máximo, determinando providências concretas para sua realização. Sobre essas premissas é que se assenta a investigaçáo acerca do significado específico do direito do consumidor e sua previsão expressa na Constituição de 1988, como direito fundamental (artigo 50, XXXII) e princípio da ordem econômica (artigo 170, V). A importância deste exame se destaca, sobretudo quando existam situaçóes específicas de aparente colisão destes direitos com outros, de fundamento jurídico diverso, como sáo exemplos as normas de proteçáo ao consumidor e as exigências administrativas (inclusive veiculadas por intermédio de normas administrativas) de prestação de serviços públicos, ou mesmo a definição dos âmbitos de aplicação das normas do Código de Defesa do Consumidor em relação às situações reguladas pelo Código Civil. (sic). (MIRAGEM, 2016, p. 56-58). 
Tal como elucidado pelo renomado jurista, o direito consumerista parte do pressuposto de que o consumidor é a parte mais fraca da relaçáo de consumo, tanto é que a própria lei que veio a atender ao comando constitucional do art. 48 do ADCT é denominada "Código de Defesa do Consumidor", deixando claro, portanto, que visa, primordialmente, a defesa dos direitos de um dos sujeitos da relação de consumo.

A constatação de vulnerabilidade do consumidor face ao fornecedor tem fundamento. É que, evidentemente, ele está em desvantagem, ao menos técnica, em relação ao outro polo, já que toda expertise relacionada à produção e fornecimento do produto/serviço pertence ao fornecedor.

Mas não é só isso, muitas vezes, a inferioridade do consumidor é também econômica, jurídica, procedimental, dentre outros, o que leva, em diversas ocasióes, ao cometimento de abusos por parte do (s) fornecedor (es), por exemplo, na elaboração do contrato de adesão (sobre o qual o consumidor não tem qualquer influência).

Tanto é assim, que o próprio CDC, em seu art. $4^{\circ}$, consignou:

Art. 4o A Política Nacional das Relaçóes de Consumo tem por objetivo o atendimento das necessidades dos consumidores, o respeito à sua dignidade, saúde e segurança, a proteção de seus interesses econômicos, a melhoria da sua qualidade de vida, bem como a transparência e harmonia das relações de consumo, atendidos os seguintes princípios:

I - reconhecimento da vulnerabilidade do consumidor no mercado de consumo. (BRASIL, 1990).

Por consequência, o CDC pretende equalizar a situação do consumidor frente ao consumidor, tal como doutrina Humberto Teodoro Junior:

A criação do Direito do Consumidor como uma disciplina autônoma tornou-se necessária, em razão da evidente superioridade do fornecedor frente ao consumidor em suas relaçóes contratuais. Se é certo que a sociedade de consumo trouxe benefícios, "em certos casos, a posição do consumidor, dentro desse modelo, piorou em vez de melhorar", na medida em que "agora é o fornecedor (fabricante, produtor, construtor, importador ou comerciante) que, inegavelmente, assume a posiçáo de força na relação de consumo e, por isso mesmo, 'dita as regras'".

Tendo em vista que o mercado não consegue, por si mesmo, superar esse desequilíbrio, tornou-se imprescindível a intervenção estatal, consubstanciada na edição de um Código de Defesa do Consumidor. Assim, a legislação deve abarcar todas as facetas do mercado, a fim de se lograr uma proteçáo integral, de modo que regule "todos os aspectos da relação de consumo, sejam aqueles pertinentes aos próprios produtos e serviços, sejam outros que se manifestam como verdadeiros instrumentos fundamentais para a produção e circulação destes mesmos bens: o crédito e o marketing". (JUNIOR, 2017, p. 22).

Feitas essas consideraçóes, é preciso entender a natureza das normas preconizadas no CDC, as quais, pela redação de seu art. $1^{\circ}$ são de "ordem pública e interesse social", o que indica, já de início, suas características de serem "cogentes e inderrogáveis pela vontade das partes" (GARCIA, 2017, p. 22).

Dizer que as normas são de ordem pública, implica em admitir que elas possam ser reconhecidas de ofício pelo magistrado, à exceção dos contratos bancários, por determinação 
expressa da Súmula 381 do STJ: "nos contratos bancários, é vedado ao julgador conhecer, de ofício, da abusividade das cláusulas".

Já, o reconhecimento quanto ao seu interesse social, culmina na conclusão de que, certamente, as normas consumeristas importam e influenciam para a sociedade como um todo. A respeito do assunto, Leonardo Medeiros de Garcia ensina:

Á primeira vista, a relação entre particular e fornecedor em nada interessa à sociedade. Ocorre que, quando o fornecedor comete abusos frente ao consumidor, como, por exemplo, quando deixa de consertar o produto vendido com defeito, e não sofre qualquer sanção pela prática abusiva, amanhã, outros consumidores estarão sofrendo os mesmos abusos. Não bastasse, outros fornecedores provavelmente praticarão as mesmas condutas abusivas, uma vez que, consertar produtos defeituosos (como no exemplo citado) ou, em sentido amplo, respeitar os direitos dos consumidores, gera custos, o pensamento seria: se a empresa "A" fez e não acontece nada, também vou fazer porque é mais lucrativo. (GARCIA, 2017, p. 24).

Assim, torna-se importante identificar em que circunstâncias as normas de ordem pública e interesse social previstas no $\mathrm{CDC}$ serão aplicáveis.

\subsection{Aplicação do Código de Defesa do Consumidor}

A compreensão exata do âmbito de abrangência do CDC pressupóe o conhecimento quanto ao conceito de "relação de consumo", o que não é de difícil compreensão.

Destarte, temos que a ligação existente entre um ou mais consumidor (es) e um ou mais fornecedor (es) em que haja a compra/venda de um produto ou a prestação/utilização de um serviço é a relação importante para o ramo do Direito em comento.

Pois bem, o polo vulnerável da relação - consumidor, conforme trazido na lei (art. 2o do CDC), é "toda pessoa física ou jurídica que adquire ou utiliza produto ou serviço como destinatário final".

A priori, o referido conceito parece de simples assimilação, entretanto, como não poderia deixar de ser, pois existem controvérsias acerca de sua delimitação, o que nos faz recorrer à doutrina e jurisprudência.

E a celeuma está justamente na amplitude do termo "destinatário final", sendo que a doutrina seguiu duas vertentes: (a) a primeira delas entende que consumidor é qualquer sujeito que adquire um produto posto no mercado - teoria maximalista; já a (b) teoria finalista, hoje majoritária dentre os doutrinadores, defende que ostentar a condição de destinatário final implica em retirar o produto da linha de produção, isto é, adquirir o produto sem a finalidade de exercer atividade profissional.

Fato é que, longe de ser um entendimento pacificado nos tribunais, o STJ adotou a teoria do "finalismo aprofundado/mitigado", a qual argumenta que, geralmente, o consumidor é o destinatário final, mas esta premissa não é inflexível, sendo preciso moderar tal regra por meio de uma análise mais profunda do caso concreto, avaliando a vulnerabilidade (técnica, jurídica, fática, informacional, etc) do consumidor.

Assim, resumidamente: 
O conceito básico de consumidor foi fixado no CDC, em seu art. $2^{\circ}$, ao estatuir que "consumidor é toda pessoa física ou jurídica que adquire ou utiliza produto ou serviço como destinatária final”. A nota característica dessa definição está na identificação de uma pessoa (física ou jurídica) como destinatária final de um produto ou serviço para que possa ser enquadrada como consumidora. A condiçáo de destinatário final de um bem ou serviço constitui a principal limitação estabelecida pelo legislador para a fixação do conceito de consumidor e, consequentemente, para a própria incidência do CDC como lei especial. Há necessidade, assim, de se estabelecer o alcance dessa expressáo, que constitui o elemento teleológico dessa definição. Considera-se destinatário final aquele que, no ato de consumir, retira o bem do mercado. Seguindo nessa linha de raciocínio, a Segunda Seção acabou por firmar entendimento centrado na teoria subjetiva ou finalista (REsp 541.867-BA, DJe 16/5/2005), posição hoje consolidada no âmbito deste STJ. Porém, a jurisprudência, posteriormente, evoluiu para admitir uma certa mitigação da teoria finalista na hipótese em que, embora não verificada a condição de destinatário final, constata-se a vulnerabilidade do consumidor profissional ante o fornecedor (REsp 1.442.674-PR, Rel. Min. Paulo de Tarso Sanseverino, julgado em 7/3/2017, DJe 30/3/2017).

Mas é preciso deixar bem que claro que tais considerações remetem à definição do consumidor comum, aquele que efetivamente participa da relação de consumo, denominado pela doutrina como "strictu sensu" ou "standard". No entanto, existem outros sujeitos que o CDC considera como consumidores para fins de proteção legal, isto é, são consumidores por equiparaçáo, ou, como chama a doutrina, "lato sensu" ou "bystander".

Estes últimos são consumidores espectadores, uma vez que alheios à relação de consumo propriamente dita, os quais serão protegidos pela legislação consumerista em situaçóes específicas nela previstas, quais sejam: (a) "a coletividade de pessoas, ainda que indetermináveis, que haja intervindo nas relaçôes de consumo", conforme dicção do parágrafo único do art. $2^{\circ}$ do $\mathrm{CDC}$; (b) as vítimas de acidente de consumo, tal como determina o art. 17 do $\mathrm{CDC}$; e (c) as pessoas expostas às práticas comerciais previstas nos arts. 30 a 54 do CDC, o que é extraído do texto do art. 29 da mesma lei.

Nesse sentido, por exemplo, embora não tenha adquirido o veículo que, por causa de um problema de fábrica, causou um acidente, um terceiro vítima deste poderá conclamar os direitos previstos no $\mathrm{CDC}$ como se consumidor padrão fosse.

Já a outra parte da relação de consumo, o fornecedor, é, conforme art. $3^{\circ}$ do CDC:

Toda pessoa física ou jurídica, pública ou privada, nacional ou estrangeira, bem como os entes despersonalizados, que desenvolvem atividades de produção, montagem, criação, construção, transformação, importação, exportação, distribuição ou comercialização de produtos ou prestação de serviços. (BRASIL, 1990).

A respeito do fornecedor, não há muitos comentários a serem tecidos, a não ser de que eles fornecem produtos e serviços, cujos conceitos também foram delimitados pelo CDC nos parágrafos do art. $3^{\circ}$ :

$\$ 1^{\circ}$ Produto é qualquer bem, móvel ou imóvel, material ou imaterial.

$\$ 2^{\circ}$ Serviço é qualquer atividade fornecida no mercado de consumo, mediante remuneraçáo, inclusive as de natureza bancária, financeira, de crédito e securitária, salvo as decorrentes das relações de caráter trabalhista. (BRASIL, 1990). 
Não e demais lembrar que, conforme previsão da Súmula 297 do STJ, o CDC é aplicável às instituiçóes financeiras.

Importante frisar, ainda, que, conquanto a relação entre consumidor e fornecedor seja onerosa, isto é, o consumidor adquire o produto/serviço mediante remuneração ao fornecedor, esta contrapartida poderá ser indireta.

Para exemplificar, cita-se a situação em que determinado estabelecimento comercial fornece estacionamento gratuito aos seus clientes. É evidente que tal prática atrai mais consumidores, no entanto não há remuneração direta pelo serviço de estacionamento, o que, como dito, não lhe retirará a condição de relação de consumo caso haja falha na sua prestação.

Em suma, o fornecedor é a parte da relação de consumo que fornece os produtos/ serviços de forma habitual, com profissionalismo. Sobre este aspecto, Leonardo de Garcia Medeiros é assertivo, ao explicar que:

A chave para se encontrar a figura do fornecedor está na expressão "desenvolvem atividade". Ou seja, somente será fornecedor o agente que pratica determinada atividade com habitualidade. Nesse sentido, quando a escola oferece cursos não gratuitos no mercado, por praticar (desenvolver) a atividade de ensino, será considerada fornecedor. Agora, quando essa mesma escola resolve vender o veículo que serve para transportar professores, não estará atuando com habitualidade, pois não desenvolve a atividade de compra e venda de veículos. Nesse caso, ainda que esse tenha do outro lado uma pessoa física adquirindo o veículo, a escola não será considerada fornecedora, não se estabelecendo, portanto, uma relação de consumo. (MEDEIROS, 2017, p. 37).

Portanto, se houver um vínculo jurídico decorrente de lei ou de contrato, entre duas ou mais pessoas (físicas ou jurídicas), em que uma delas se enquadre no conceito de consumidor e outra no de fornecedor, haverá uma relação de consumo, objeto do Direito do Consumidor.

E estas relaçóes, como já dito, serão reguladas pelo CDC, sendo relevante lembrar que as relaçôes trabalhistas e aquelas que, embora dotadas das características de uma relação de consumo, sejam gratuitas, estão excluídas da sua tutela.

Uma vez constatada a existência da relação de consumo, é importante avaliar quais são os direitos que a lei consumerista garante aos consumidores.

\subsection{Direitos básicos do consumidor}

Comprometendo-se em promover a defesa do consumidor, como determina a Constituição Federal de 1988, o CDC estabeleceu, nos incisos do art. $6^{\circ}$ os seus direitos básicos.

$\mathrm{O}$ primeiro deles, previsto no inciso I do art. $6^{\circ}$ é o direito à "a proteção da vida, saúde e segurança contra os riscos provocados por práticas no fornecimento de produtos e serviços considerados perigosos ou nocivos".

Conforme ensina Bruno Miragem, a proteção da vida revela-se o direito mais essencial, que assume duas facetas: 
(...) Por um lado, determina a proteção da vida do consumidor individualmente considerado em uma relaçáo de consumo específica, o que indica a necessidade de proteçáo da sua integridade física e moral, e, neste sentido, o vínculo de dependência da efetividade deste direito com os demais de proteção da saúde e da segurança (...).

Uma segunda dimensão, que podemos indicar como dimensão transindividual do direito à vida, é sua proteção de modo comum e geral a toda a coletividade de consumidores efetivos e potenciais, com relação aos riscos e demais vicissitudes do mercado de consumo, o que no caso, determina a vinculação deste direito subjetivo e outros como o direito à segurança, e ao meio ambiente sadio. (MIRAGEM, 2016, p. 211).

Portanto, em resumo, o direito acima referenciado do consumidor se traduz na obrigação de que o fornecedor, no exercício de sua atividade, não pratique condutas que possam prejudicar a vida, saúde e segurança do consumidor, e tomem medidas efetivas para garanti-los.

O segundo direito básico do consumidor é o de "educação e divulgação sobre o consumo adequado dos produtos e serviços, asseguradas a liberdade de escolha e a igualdade nas contrataçôes".

Também de extrema importância, a referida prerrogativa garante ao consumidor a possibilidade de escolher um produto ou serviço que achar conveniente, mais barato ou de melhor qualidade, sem qualquer interferência abusiva do fornecedor, inclusive coibindo práticas que tolham sua liberdade.

Nesse sentido, é importante que o consumidor seja educado para o consumo, que ele tenha consciência das consequências de utilização de cada produto/serviço.

O inciso III do art. $6^{\circ}$ traz o direito "a informaçáo adequada e clara sobre os diferentes produtos e serviços, com especificação correta de quantidade, características, composição, qualidade, tributos incidentes e preço, bem como sobre os riscos que apresentem".

Claramente interligado o com o direito anterior, a referida faculdade garante ao consumidor o direito de conhecer exatamente o produto ou serviço que pretende adquirir. Tal direito implica, ainda, em sançóes ao fornecedor que prover produtos ou serviços em desacordo com as informaçóes apresentadas, por exemplo, determinado alimento que possui um conteúdo quantitativamente inferior ao informado na embalagem.

Já o quarto direito básico do consumidor relaciona-se com a "a proteção contra a publicidade enganosa e abusiva, métodos comerciais coercitivos ou desleais, bem como contra práticas e cláusulas abusivas ou impostas no fornecimento de produtos e serviços".

Assim, ensina Claudia Lima Marques:

O inciso IV do art. $6^{\circ}$ do CDC proíbe o abuso de direito e impóe transparência e boa-fé nos métodos comerciais, na publicidade e nos contratos. Como vimos, é possível afirmar que a boa-fé é o princípio máximo orientador do CDC; aqui também o princípio da transparência (art. $4^{\circ}$, caput) atua como um reflexo da boa-fé exigida aos agentes contratuais. O CDC preocupa-se tanto com os aspectos pré-contratuais como os de formação e execução dos contratos de consumo. (MARQUES, 2002, p. 75).

O quinto direito básico previsto no CDC, também é correlato ao anterior, pois garante ao consumidor "a modificaçâo das cláusulas contratuais que estabeleçam 
prestações desproporcionais ou sua revisão em razão de fatos supervenientes que as tornem excessivamente onerosas".

Assim sendo, quando, na fase de formação dos contratos, houver desrespeito ao consumidor, lhe será assegurada a possibilidade de alteração das cláusulas abusivas.

A previsão do inciso VI do art. $6^{\circ}$ do CDC é do direito à "efetiva prevenção e reparação de danos patrimoniais e morais, individuais, coletivos e difuso", o que se dá por meio da responsabilização, em regra objetiva, do fornecedor pelos vícios e defeitos dos produtos/serviços.

Mas não é só isso, além das políticas visando a concreta reparação de danos, como se pode observar, deve haver também a efetiva prevenção dos mesmos, o que implica em dizer que atuação dos fornecedores, na produção e execução de sua atividade, deve sempre buscar evitar a ocorrência de danos futuros aos consumidores.

Claudia de Lima Marques (2002) lembra, ainda, que tal direito está relacionado com a possibilidade de desconsideração da personalidade jurídica, tal como previsto no art. 28 do CDC.

Como corolário ao referido direito, o consumidor terá, também, como sétimo direito básico, o "acesso aos órgãos judiciários e administrativos com vistas à prevenção ou reparação de danos patrimoniais e morais, individuais, coletivos ou difusos, assegurada a proteção Jurídica, administrativa e técnica aos necessitados”.

Sem muitas delongas, esta prerrogativa impóe ao estado o dever de atender aos anseios do consumidor, no sentido de tomar medidas que previnam e reparem danos sofridos nas relações de consumo.

O oitavo direito básico do consumidor previsto no inciso VIII do art. $6^{\circ}$ do CDC, por sua vez, é o de

facilitação da defesa de seus direitos, inclusive com a inversão do ônus da prova, a seu favor, no processo civil, quando, a critério do juiz, for verossímil a alegação ou quando for ele hipossuficiente, segundo as regras ordinárias de experiências. (BRASIL, 1990).

Tal como doutrina de Bruno Miragem:

O direito à facilitação da defesa, apresenta-se, em termos processuais, pela possibilidade de inversão do ônus da prova no processo civil. As razóes para seu reconhecimento é a dificuldade prática dos consumidores de demonstrar os elementos fáticos que suportam sua pretensão. Ora, na estrutura das relaçóes de consumo, o domínio do conhecimento sobre o produto ou o serviço, ou ainda sobre o processo de produçáo e fornecimento dos mesmos no mercado de consumo é do fornecedor. Da mesma forma, náo se pode desconhecer que a defesa judicial de interesses exige do titular da pretensão a disposição de recursos financeiros e técnicos para uma adequada demonstração da pertinência e procedência do seu interesse. (MIRAGEM, 2016, p. 234).

Entretanto, o mesmo autor (2017) lembra que tal garantia não desobriga o magistrado de avaliar a existência de hipossuficiência do consumidor ou da verossimilhança das alegaçóes, sendo certo que, os conceitos de hipossuficiência e vulnerabilidade são distintos. 
Por fim, o último direito básico do consumidor elencado no art. $6^{\circ}$ é o de "adequada e eficaz prestação dos serviços públicos em geral". Conforme ensina Claudia Lima Marques (2002), tal direito apenas completa o direito à prevenção e reparação de danos previsto no inciso VI do art. $6^{\circ}$ do CDC e será integrado pelo art. 22 e os demais que tratam dos serviços públicos.

Verifica-se, entáo, que o CDC estabelece uma gama de direitos que, por sua vez, desembocarão em outros direitos e obrigaçôes que visam a defesa do consumidor.

Tais direitos se relacionam diretamente com os princípios que norteiam o CDC, previstos, dentre outros, no art. $4^{\circ}$ do referido diploma legal, e relacionados pela doutrina especializada.

Conforme já citado em algumas passagens deste capítulo, todo o sistema protetivo criado pelo CDC parte do pressuposto de vulnerabilidade do consumidor e gira em torno de sua defesa, em todos os aspectos, inclusive de saúde física e intelectual.

Assim sendo, práticas dos fornecedores que prejudiquem o meio ambiente afetam diretamente ao consumidor, e, consequentemente, à sociedade como um todo, como se verá a seguir.

\section{ASPECTOS GERAIS SOBRE O CASO DIESELGATE DA VOLKSWAGEN}

A terminologia Dieselgate foi dada pelos veículos de comunicaçóes ao escândalo automobilístico descoberto e levado à público referente às adulteraçóes dos laudos e testes de emissóes de poluentes nocivos ao meio ambiente em veículos de diversas marcas ocorrido em 2015, sendo certo que o presente estudo tem como foco o caso específico da montadora Volkswagen.

Tendo em vista que a referida fabricante é uma montadora de veículos de vários portes, sendo proprietária de notáveis marcas de veículos como a Porsche e a Audi, a mesma se enquadra no conceito de fornecedor, tal como explanado no capítulo anterior.

No caso em comento, a fornecedora instalou um software em todos os veículos que possuíam o motor a diesel, para que no ato da inspeção pelo órgão competente, o lote fosse aprovado quanto ao requisito de baixa emissão de poluentes ao meio ambiente, entretanto, a realidade era que os veículos emitiam cerca de 19 a 65 vezes mais poluentes que o permitido.

Nesse rumo, é possível perceber que a fabricante Volkswagen violou prerrogativas básicas do consumidor, que, em sua maioria, se traduzem em obrigaçôes do fornecedor, tais como: o direito à vida, saúde, segurança, bem como infringiu a proibição de perpetração de propaganda enganosa.

Portanto, a prática prejudicou não somente o meio ambiente, visto que houve a fabricação e comercialização de milhares de veículos que poluíam mais que o permitido pelas legislaçóes dos países a que eram destinados, mas também os consumidores, já que, como dito, o objetivo final da montadora é de comercializar veículos, seja para as pessoas físicas, como para as pessoas jurídicas. 
É possível observar que o prejuízo ao consumidor, então, ocorreu de forma direta e indireta. Diretamente porque eles estavam adquirindo um produto que náo correspondia ao que foi prometido. Indiretamente, mas não menos grave, porque a degradação do meio ambiente atinge em proporçóes enormes a qualidade de vida de toda a população.

Aliás, considerando as espécies de consumidor elencadas no capítulo 2, é possível afirmar que grande número de pessoas foi afetada pela prática, o que implica em que são consideradas como consumidores por equiparação.

Assim sendo, percebe-se que a prática da Volkswagen feriu diversos preceitos jurídicos, seja no âmbito ambiental, penal, civil e, especialmente, consumerista, pois, sendo importante ter sempre em mente que consumidor é a parte mais frágil na relação de consumo, tanto que ensejou, no Brasil, a criação de uma legislação totalmente protecionista, conforme visto no capítulo acima.

\title{
3.1 O princípio da boa-fé objetiva nas relaçóes consumeristas
}

Como todos os ramos do Direito são moldados por princípios, o ramo do Direito do Consumidor não é diferente, visto a sua relevância para a vida social e comunitária. Assim, além de direitos básicos destinados à proteção do consumidor, existem também princípios norteadores que devem balizar as relaçóes de consumo.

De Plácido e Silva (2013, p. 1097) em sua obra expóe que "princípio é também a expressão que designa a espécie de norma jurídica cujo conteúdo é genérico, contrapondose à regra ou ao preceito, que é a norma mais individualizada".

Nesse mesmo sentido, tal autor conclui:

\begin{abstract}
Notadamente no plural, princípios significam as normas elementares ou os requisitos primordiais instituídos como base, como alicerce de alguma coisa. E, assim, princípios revelam o conjunto de regras ou preceitos, que se fixam para servir de norma a toda espécie de ação jurídica, traçando, assim, a conduta a ser tida em qualquer operação jurídica. Desse modo, exprimem sentido mais relevante que o da própria norma ou regra jurídica. Mostram-se a própria razão fundamental de ser das coisas jurídicas, convertendo-se em perfeitos axiomas. Princípios jurídicos, sem dúvida, significam os pontos básicos, que servem de ponto de partida ou de elementos vitais do próprio Direito. Indicam o alicerce do Direito. (SILVA, p. 1097).
\end{abstract}

É fato que a ética e a boa-fé devem presumir qualquer tipo de situação e conduta no mundo real, dada a sua importância nas relaçóes interpessoais. Nas relaçóes contratuais, o princípio da boa-fé igualmente teria de ser o principal aspecto da relação, visto a sua relevância para ambas às partes.

É perfeitamente possível traçar um paralelo entre a autonomia da vontade e boa-fé objetiva nas relaçôes consumeristas, pois ambas são alicerçadas na confiança, e a boa-fé objetiva nada mais é que a confiança de uma parte na outra, no sentido que esta não irá lesar a outra por sua própria vontade.

Neste norte, Laerte Marrone de Castro Sampaio expóe: 
$\mathrm{Na}$ primeira referência, inserida no título relativo à política nacional das relações de consumo, a boa-fé objetiva aparece como princípio orientador da interpretação, de molde que viabilize os valores nos quais se funda a ordem econômica (art. 170 da Constituição Federal). Num segundo momento (art. 51, IV), a boa-fé é chamada para servir como medida da abusividade das cláusulas contratuais, permitindo ao juiz interferir no pactuado entre as partes, a fim de garantir o equilíbrio contratual. (SAMPAIO, 2004, p. 41-42).

No que tange especificamente ao princípio da boa-fé, os autores Flávio Tartuce e Daniel Amorim Assumpção Neves (2013, p. 38), discorrem que "a boa-fé objetiva traz a ideia de equilíbrio negocial, que, na ótica do Direito do Consumidor, deve ser mantido em todos os momentos pelos quais passa o negócio jurídico".

Da mesma maneira, Ricardo Resende explica:

Segundo este princípio, tanto o empregado, quanto o empregador devem agir, em sua relação, pautados pela lealdade e boa-fé. Em que pese ter sido encartado por Plá Rodriguez como princípio especial trabalhista, a maioria da doutrina brasileira se posiciona no sentido de que este é um princípio geral do direito, aplicável a todos os ramos da ciência jurídica. Este entendimento restou cristalizado pelo artigo 422 do Código Civil de 2002, o qual dispóe que os contratantes são obrigados a guardar, assim na conclusão do contrato, como em sua execução, os princípios de probidade e boa-fé. (REZENDE, 2014, p. 21).

A partir do momento em que as relaçóes contratuais consumeristas estáo norteadas sob o princípio da boa-fé objetiva, nenhuma das partes deve possuir como objetivo lesar a outra, mas sim entregar aquilo que foi pactuado entre elas.

Nesse esteio e de forma taxativa o caso o Dieselgate da Volkswagen é claro exemplo de inobservância de todos os pressupostos de uma boa relação contratual, visto que a fabricante sabia dos problemas que os veículos apresentavam e mesmo assim efetuou a sua comercialização, utilizando-se de artimanha para tanto.

Sobre o assunto, o autor José Junior (2016, p. 104), versa que "a boa-fé tem como pressuposto a existência de uma obrigação e de um direito correlatos, dentro de uma relação jurídica, e deriva da máxima romana neminem laedere, ou seja, da intenção de não lesar ninguém".

A própria Constituição Federal Brasileira, em seu artigo $3^{\circ}$, I, destaca que o Brasil possui como diretriz a boa-fé como princípio social, tendo em vista que a sociedade deve ser livre, justa e solidária.

Portanto, o princípio da boa-fé objetiva deve permear todas as relaçóes de consumo, já que deve haver reciprocidade entre as partes da relação contratual.

\section{O "COMUM" E AS DIVERGÊNCIAS NAS RELAÇÓES ENTRE FORNECEDORES E CONSUMIDORES}

Utilizando-se a expressão "comum", os autores Pierre Dardot e Christian Laval na obra "Comum: ensaios sobre a revolução no século XXI", é possível compreender a influência que o capitalista opressor possui em relação àqueles que detém um menor poder negocial nas relaçôes consumeristas - os consumidores, bem como a determinância do 
poder político para concentrar na seara privada bens que são comuns a todos, como por exemplo o meio ambiente, e a água.

Nota-se que com o passar dos anos cada vez mais o poder político influencia a dinâmica social, onde a vontade privada se sobrepóe em relação à pública, e como exemplo no âmbito do direito brasileiro podemos citar a reforma trabalhista que extinguiu diversos direitos dos trabalhadores, como as horas in itineres, o fracionamento das férias e diversos outros direitos que foram abolidos simplesmente pela vontade política e privada se sobrepor aos direitos da maioria.

Dessa forma, o termo "comum" utilizado pelos autores faz um contraponto e uma crítica a esta constatação de que a minoria da sociedade que detém a maior percentual da riqueza do mundo dita as normas, bem como usa da vontade privada para o benefício próprio.

Nesse sentido, Pierre Dardot e Christian Laval dissertam:

\begin{abstract}
Lembramos que por "comuns" se entende primeiramente o conjunto de regras que permitia aos camponeses de uma mesma comunidade o uso coletivo de caminhos, florestas e pastos, segundo o costume. O termo recebeu conteúdo mais amplo, compreendendo tudo o que pudesse se tornar alvo de privatizaçóes, processos de mercantilizaçáo, pilhagens e destruiçóes realizados em nome ou a pretexto do neoliberalismo. Hoje o termo tem valor crítico, tornou-se o significante oponível à grande apropriação das riquezas que caracterizou as últimas décadas, a fórmula que, por sua lógica reversa, designa a grande pilhagem praticada pela pequena oligarquia do " $1 \%$ " denunciada pelos ocupantes do Zucotti Park, em Nova York. (DARDOT; LAVAL, 2017, p. 102).
\end{abstract}

Portanto, é possível perceber que o movimento do comum surge da convergência de preocupaçóes, aspiraçóes e novas possibilidades de agir coletivamente contra tudo aquilo que venha a destruir as condiçóes de existência atuais, sejam elas climáticas, destruiçóes de ativos e serviços públicos, dentre outros. Assim, se faz importante também destacar que o modo de produção atual foi alterado baseando-se na vontade privada daqueles que detém o capital, como se pode verificar no caso Dieselgate da Volkswagen, onde a força privada se impôs à vontade pública e aos direitos legitimados na lei consumerista.

Sendo o movimento do "comum" uma preocupação com as condições existenciais das práticas atuais, no caso Dieselgate da Volkswagen, constata-se lesão a direitos de terceiros, motivadas pelo anseio de diminuição das despesas que seriam derivadas da correta adequação dos veículos para a sua comercialização.

Dessa forma, pode-se dizer que o movimento do "comum" se preocupa com as posiçóes daqueles que possuem a grande parcela do capital mundial no sentido de que os direitos daqueles que são mais frágeis nas relações políticas e negociais não sejam infringidos.

\title{
4.1 O capitalismo e a responsabilidade civil
}

O capitalismo exacerbado do século XXI coloca em risco as relaçóes entre os particulares, visto que, objetivando maximizar a obtenção de riqueza, as empresas privadas deixam de lado a excelência na prestação dos serviços ou na entrega dos produtos. 
O comportamento humano é falho e historicamente os seres humanos adotam alguns tipos de condutas que ferem e restringem direitos de terceiros, sendo o papel do Direito assegurar aos lesados um mecanismo de reparação integral e eficiente.

O caso da Dieselgate da Volkswagen é um exemplo de prática abusiva do fornecedor, pois a montadora omitiu ao seu público e aos órgáos fiscalizados competentes que os seus veículos de motores a diesel estavam inaptos para comercialização, o que configura conduta tipicamente ensejadora de reparação civil.

Quando se fala em responsabilidade deve-se inicialmente versar sobre a atribuição de efeitos, onde o ato ou a omissáo de determinada conduta trará consequências para o mundo real.

O doutrinador Rogério Sampaio (2003, p. 17) destaca que "o instituto da responsabilidade civil é parte integrante do direito obrigacional, que consiste na obrigação que tem o autor de um ato ilícito de indenizar a vítima pelos prejuízos causados pela sua conduta".

Neste esteio, a responsabilidade civil possui como supedâneo a obrigação de reparação do dano causado culposa ou dolosamente.

A doutrina majoritária na seara do direito brasileiro assim dispóe sobre a matéria:

Designa a obrigaçáo de reparar o dano ou de ressarcir o dano, quando injustamente causado a outrem. Revela-se, assim, ou melhor, resulta da ofensa ou da violaçáo de direito, que redunda em dano ou prejuízo a outrem. A responsabilidade civil é a que se apura para que se possa exigir a reparaçáo civil, que é a pena imposta ao agente ou responsável pelo ato ilícito. (SILVA, 2013, p. 1223).

Dessa forma, a partir do momento em que determinado indivíduo comete algum ato ilícito, bem com deixa de cumprir determinada obrigaçáo contratual que lhe era correspondente, o mesmo irá responder por aquela prática na seara judicial, ou por sua omissão, devendo indenizar aquele que foi alvo do dano.

Humberto Theodoro Júnior dispóe que:

a base da responsabilidade civil encontra-se o descumprimento de um dever, que, sendo conscientemente violado, configura um ilícito (um delito civil), sendo a sanção jurídica imposta ao agente desse ilícito é a obrigação de reparar o prejuízo acarretado à vítima. (JÚNIOR, 2011, p. 19).

Assim, observa-se a existência de duas modalidades de responsabilidade civil: objetiva subjetiva. Quanto à responsabilidade civil objetiva, a doutrina ensina que independe de culpa do agente para que haja a obrigação de reparar o dano. Já a responsabilidade civil subjetiva está condicionada à existência de culpa ou dolo por parte do agente que praticou a conduta causadora do dano.

Nesse esteio, o autor Arnaldo Rizzardo (2015, p. 406) destaca que a "responsabilidade objetiva incide somente no dever de indenizar pela mera ocorrência do fato danoso". 
Com efeito, fica evidente que o instituto da responsabilidade civil visa proteger a sociedade dos atos ilícitos cometidos por terceiros, seja o agente o poder público, pessoas físicas ou jurídicas, a partir das suas condutas que causem dano e prejuízo, seja omissiva ou comissiva, apreciando assim o nexo causal no caso concreto.

No tocante à legislação consumerista, o modelo de responsabilidade adotada como regra é a objetiva, assim, o fornecedor responderá independentemente de culpa pelos danos que causar ao consumidor, tal como preconizam os caputs dos artigos 12 e 14 do CDC:

Art. 12. O fabricante, o produtor, o construtor, nacional ou estrangeiro, e o importador respondem, independentemente da existência de culpa, pela reparação dos danos causados aos consumidores por defeitos decorrentes de projeto, fabricação, construçấo, montagem, fórmulas, manipulação, apresentação ou acondicionamento de seus produtos, bem como por informaçôes insuficientes ou inadequadas sobre sua utilização e riscos.

Art. 14. O fornecedor de serviços responde, independentemente da existência de culpa, pela reparaçấo dos danos causados aos consumidores por defeitos relativos à prestação dos serviços, bem como por informaçóes insuficientes ou inadequadas sobre sua fruição e riscos. (BRASIL, 1990).

Não obstante, é preciso destacar que a exceção está justamente na prestação de serviços por profissionais liberais, conforme determinaçáo do parágrafo $4^{\circ}$ do artigo 14: "a responsabilidade pessoal dos profissionais liberais será apurada mediante a verificação de culpa".

Portanto, tendo como base todo o exposto, é evidente que a prática da Volkswagem enseja a sua responsabilização civil independentemente da aferição de culpa.

\section{CONCLUSÃO}

A relação de consumo é uma das práticas mais antigas da humanidade, que tomou inegável proporçáo no período das grandes navegaçóes, na qual o escambo beneficiava tanto o consumidor quanto o fornecedor, sendo certo que no decorrer dos séculos essas práticas consumeristas foram se aperfeiçoando até chegar nos moldes atuais.

O Código de Defesa do Consumidor brasileiro é categórico ao versar que as relaçōes entre consumidores e fornecedores devem ser pautadas na verdade, de forma que um dos seus princípios mais importantes é o da boa-fé objetiva, que estabelece que nenhuma das partes deve conscientemente lesar a outra.

É evidente, ainda, que o Código de Defesa do Consumidor reconhece a vulnerabilidade do consumidor frente ao fornecedor, razão pela qual, além da obrigação imposta de agir sempre com boa-fé, os fornecedores devem estar atentos também à gama de direitos nele previstos que tem como objetivo a proteçáo do consumidor.

No caso analisado neste artigo, a fabricante Volkswagen deixou de observar as bases de uma correta relação consumerista, já que optou por comercializar veículos em desacordo com normas de proteçáo ao meio ambiente, mesmo conhecendo o grande potencial lesivo que a prática traria ao consumidor, agindo, assim, em patente má-fé e desrespeitando diversos direitos básicos do consumidor. 
Mas não é só isso, a prática foi perpetrada por meio de fraude no processo de obtenção da autorização para comercialização dos veículos, o que demonstra a desmedida busca por lucro a todo custo.

Dessa maneira, é totalmente pertinente o caso concreto com a utilizaçáo do movimento do comum destacado pelos autores Pierre Dardot e Christian Laval, pois com a revoluçáo do capitalismo no século XXI, e com a concentraçáo da riqueza na mãos de uma minoria, tudo pode ser privatizado, ou seja, o meio ambiente, a água, os serviços públicos podem ser tornar privados e perderem a sua essência inicial, visto que o capitalismo objetiva lucros sem medir esforços, trazendo assim prejuízos para a maior e frágil parcela da sociedade, os consumidores.

\section{REFERÊNCIAS}

BENJAMIN, Antonio Herman V.; MARQUES, Claudia Lima; BESSA, Leonardo Roscoe. Manual de Direito do Consumidor. $5^{a}$ ed. rev. atual. e ampl. São Paulo: Editora Revista dos Tribunais, 2013.

BRASIL. Lei no 8.078, de 11 de Setembro de 1990. Dispóe sobre a proteção do consumidor e dá outras providências. Diário Oficial da União, Brasília, 12 de setembro de 1990.

BRASIL. Constituiçáo da República Federativa do Brasil de 1988. Vade Mecum. 22 ed. São Paulo: Saraiva, 2016.

CARVALHO, Kildare Gonçalves. Direito Constitucional Positivo. 20 ed. rev. atual. Belo Horizonte: Del Rey, 2013.

CARVALHO, Kildare Gonçalves. Teoria do Estado e da Constituiçáo. 21 ed. rev. atual. Belo Horizonte: Del Rey, 2013.

DARDOT, Pierre; LAVAL, Christian. Comum, ensaio sobre a revoluçáo no século XXI. 1. Ed. São Paulo: Boitempo, 2017.

FILOMENO, José Geraldo Brito. Direitos do Consumidor. 15. ed. rev., atual. e ref. São Paulo: Atlas, 2018.

GARCIA, Leonardo de Medeiros. Código de Defesa do Consumidor Comentado: artigo por artigo. 13 ed. rev. atual. e ampl. Salvador: JusPODVM, 2016.

GRINOVER, Ada Pellegrini. Código brasileiro de defesa do consumidor: comentado pelos autores do anteprojeto. 10 ed. rev. atual. e ampl. Rio de Janeiro: Forense, 2011, vol I.

JÚNIOR, Humberto Theodoro. Responsabilidade civil contemporânea: em homenagem a Sílvio de Salvo Venosa. $1^{\circ}$ ed. São Paulo: Atlas, 2011. 
JUNIOR, Humberto Teodoro. Direitos do Consumidor. 9a ed. ref., rev. e atual. Rio de Janeiro: Forense, 2017.

OLIVEIRA, Celso Marcelo de. Teoria geral da responsabilidade civil e de consumo. $1^{\mathrm{o}}$ ed. São Paulo: IOB Thomson, 2005.

MARTINS, Plinio Lacerda. Anotaçóes ao Código de Defesa do Consumidor: Conceitos e noçóes básicas. $2^{\mathrm{a}}$ ed. Rio de Janeiro: Forense, 2004.

MARQUES, Claudia Lima. Contratos no Código de Defesa do Consumidor: o novo regime das relaçóes contratuais. $4^{\mathrm{a}}$ ed. rev. atual. e ampl. São Paulo: Editora Revista dos Tribunais, 2002.

MIRAGEM, Bruno. Curso de Direito do Consumidor. $6^{a}$ ed. rev. atual. e ampl. Sáo Paulo; Editora Revista dos Tribunais, 2016.

RIZZARDO, Arnaldo. Responsabilidade civil. $7^{\circ}$ ed. rev. e atual. Rio de janeiro: Forense, 2015.

SILVA, De Plácido e. Vocabulário Jurídico. 30 ed. Rio de Janeiro: Forense, 2013.

TARTUCE, Flávio; NEVES, Daniel Amorim Assumpção. Manual de direito do consumidor. $2^{\circ}$ ed. Rio de Janeiro: Forense: São Paulo: Método, 2013.

TARTUCE, Flavio; NEVES, Daniel Amorim Assumpção. Manual de Direito do Consumidor: direito material e processual. $7^{\mathrm{a}} \mathrm{ed}$. rev. atual. e ampl. Rio de Janeiro: Forense, 2018.

. Revista Auto Esporte. Entenda o caso Dieselgate. Disponível em:<https:// revistaautoesporte.globo.com/Noticias/noticia/2017/03/entenda-o-caso-dieselgate.html > Acesso em: 26 Jan. 2019.

Auto papo. Dieselgate: Entenda a fraude global das emissóes. Disponível em:< https://autopapo.com.br/noticia/dieselgate-tudo-precisa-saber-fraude-volkswagen/> Acesso em: 26 Jan. 2019. 